\title{
New Philippine record of south american sailfin catfishes (Pisces: Loricariidae)
}

\author{
JOEL M. CHAVEZ ${ }^{1}$, REYNALDO M. DE LA PAZ ${ }^{1}$, SURYA KRISHNA MANOHAR ${ }^{1}$, \\ ROBERTO C. PAGULAYAN ${ }^{2} \&$ JOSE R. CARANDANG VI ${ }^{1} *$ \\ ${ }^{1}$ Biology Department, De La Salle University, Manila, Philippines \\ ${ }^{2}$ Institute of Biology, University of the Philippines, Quezon City, Philippines \\ *Author for correspondence telefax+63-2-5240451 email: carandangj@dlsu.edu.ph
}

\begin{abstract}
A taxonomic and biogeographic study of the introduced suckermouth armored catfishes locally known as "janitor fish" is briefly described. Specimens were collected from five sites in the Laguna de Bay basin and were examined for 19 meristic and 37 morphometric characters and other external features including coloration. Results were compared with existing literature on fishes in the family Loricariidae. Examination revealed that specimens of janitor fish, previously reported as Hypostomus plecostomus, actually belong to the genus Pterygoplichthys, family Loricariidae. Collected specimens consisted of two species-Pterygoplichthys disjunctivus and Pterygoplichthys pardalis. Both species were collected from the five sites except in Pasig River where only $P$. disjunctivus was collected.
\end{abstract}

Key words: Janitor fish, Pterygoplichthys, sailfin catfishes, Laguna de Bay, Philippines, introduced species

\section{Introduction}

In 2002, news reports of an introduced suckermouth armored catfish being caught in the waters of Laguna de Bay were published. The reports said that the fish was proliferating in the lake and was interfering in fishing-related activities. Apparently, the fish was being blamed for the decrease in the marketable fish catch from the lake either by replacing the usual fishes harvested or by destroying fishing nets and cages. Some national and local government agencies have also expressed concern over this problem because of the possible negative effects the fish may have on the lakes ecosystem. 
The Laguna de Bay is the largest inland body of water in the Philippines and one of the largest lakes in Southeast Asia. It serves a number of agro-industrial purposes that benefit about 11 million Filipinos. Fisheries are its main use, and approximately 3 million people depend upon the lake for a living.

The fish is locally known as "janitor fish"a moniker the fish earned because of its habit of eating algae in the tank, thus keeping the glass clean. Some reports putatively identified the janitor fish as Hypostomus plecostomus. No taxonomic records of the janitor fish in Laguna de Bay have been published, and locally available materials on the fish are minimal. A taxonomic and biogeographic investigation on the janitor fish in Laguna de Bay was conducted.

\section{Methodology}

Specimens were collected from five sites in and around the Laguna de Bay basin: Marikina River in Marikina and Pasig Cities; Pasig River in the City of Manila; Catmon Creek in Bay, Laguna; Banilad Creek in Siniloan, Laguna; and Laguna de Bay in San Pedro, Laguna. The institutional abbreviation DLSU ZC-F, which stands for De La Salle University Zoological Collection-Fishes, was used to catalog specimens. Nineteen meristic and 37 morphometric characters of the specimens were examined in accordance with the methods of Armbruster (2003a) and Armbruster and Page (1996). When possible, counts and measurements were made on the left side of the body. Distances were measured in millimeters using dial calipers and were converted to ratios of the standard length or head length. Data collected were compared with published and online literature (Armbruster 1997, 1998, 2002a, 2002b, 2003a, 2003b, 2004; Armbruster \& Hardman, 1999; Armbruster \& Page, 1996; Armbruster \& Provenzano, 2000; Armbruster et al., 2000; Weber, 1992) on Loricariidae. To compare our morphometric data with those of Weber (1992), the ratios of standard length or head length over the measured distances were computed. Other external features and coloration were also examined and compared.

\section{Results and Discussion}

The genus of the janitor fish was determined using the key by Armbruster (2002b) to the genera of family Loricariidae. Use of the key suggested that the janitor fish from Laguna de Bay belongs to the genus Pterygoplichthys (Gill 1858) and is not Hypostomus plecostomus as reported earlier. The identification of species was based on the key to the genus Pterygoplichthys sensu lato of Weber (1992) and other descriptions by Drs. Jonathan Armbruster and Claude Weber (personal communication). Nomenclature of species follows Armbruster (2004). Based on the observed coloration of 193 specimens, apparently two species of Pterygoplichthys (Gill 1858) can be found in the Laguna de Bay 


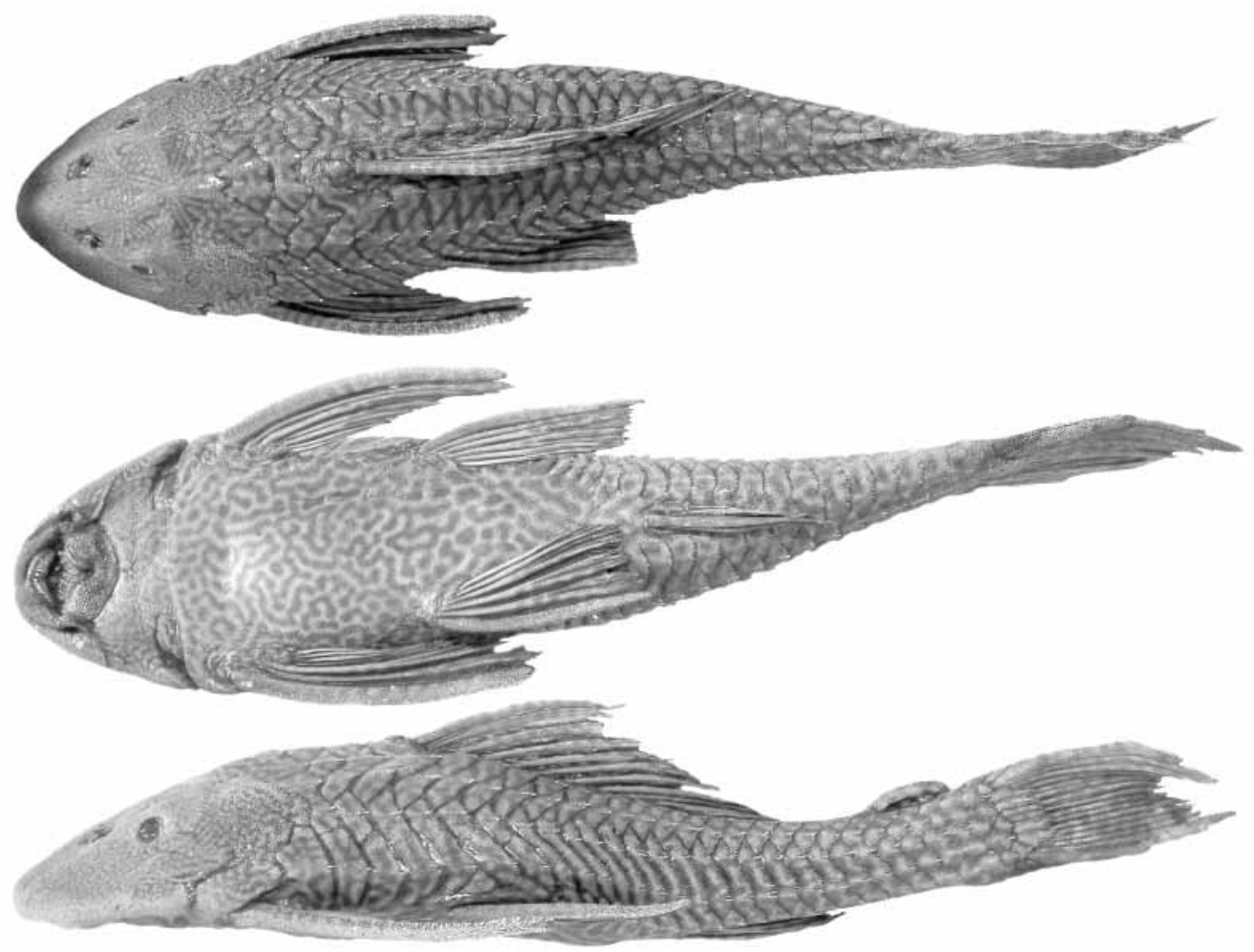

FIGURE 1. Pterygoplichthys disjunctivus from Laguna de Bay (DLSU ZC-F 51001. SL 295.0 mm. Collected by J. R. Carandang. Photo by J.M. Chavez)

Table 1 summarizes the range of variation of 16 meristic characters for the two species. Adipose fin is present in all specimens. Dentary teeth are as follows: $P$. disjunctivus 3-37 (mode=18); P. pardalis 3-42 (mode=24). Premaxillary teeth: $P$. disjunctivus 6-40 (mode $=20)$; $P$. pardalis $3-40($ mode $=25)$. Selected morphometrics of the fish samples are shown in Table 2.

Little variation in meristic counts and morphometric measurements for the two species was found when compared to data reported by Weber (2002), although a larger orbital diameter was noted among specimens of $P$. disjunctivus collected from Marikina River (Table 3).

Most of the samples have a base color of light gray usually becoming lighter towards the ventral side. Some have a dark brown base color while a few are light brown. Pterygoplichthys disjunctivus was distinguished from $P$. pardalis by the typical dark vermiculations on a light background (Fig. 3A). However, some variations on this pattern 
zootaxa were observed. Some specimens exhibit variations in the thickness of the light and dark 1109 patterns (Fig. 3B) $(n=14)$. Some specimens have the coalescent patterns on the abdomen only, these becoming spots towards the head or vent or both (Fig. 3C) $(n=21)$. Pterygoplichthys pardalis has body coloration, particularly on the abdomen, consisting of dark spots on an otherwise light background (Fig. 4). The heads of both species exhibit linear patterns forming geometric shapes.

TABLE 1. Meristic characteristics of Pterygoplichthys species caught in the Laguna de Bay area.

\begin{tabular}{|c|c|c|c|}
\hline Characters & Count & $\begin{array}{l}\text { \% P. disjunctivus } \\
(\mathrm{N}=96)\end{array}$ & $\begin{array}{l}\text { \% P. pardalis } \\
(\mathrm{N}=97)\end{array}$ \\
\hline \multirow[t]{5}{*}{ Dorsal fin rays } & 10 & 16.8 & 9.3 \\
\hline & 11 & 58.9 & 41.2 \\
\hline & 12 & $21.1^{*}$ & $44.3^{*}$ \\
\hline & 13 & 2.1 & 5.2 \\
\hline & 14 & 1.1 & 0.0 \\
\hline \multirow[t]{3}{*}{ Anal fin rays } & 3 & 1.1 & 0.0 \\
\hline & 4 & 96.8 & 99.0 \\
\hline & 5 & 2.1 & 1.0 \\
\hline \multirow[t]{3}{*}{ Caudal fin rays } & 13 & 10.5 & 4.1 \\
\hline & 14 & 89.5 & 94.8 \\
\hline & 15 & 0.0 & 1.0 \\
\hline \multirow[t]{3}{*}{ Pectoral fin rays } & 5 & 0.0 & 3.1 \\
\hline & 6 & 95.8 & 96.9 \\
\hline & 7 & 4.2 & 0.0 \\
\hline \multirow[t]{2}{*}{ Pelvic fin rays } & 5 & 96.8 & 99.0 \\
\hline & 6 & 3.2 & 1.0 \\
\hline \multirow[t]{4}{*}{ Lateral line plates } & 27 & 6.3 & 5.2 \\
\hline & 28 & 54.7 & 42.3 \\
\hline & 29 & $23.2 *$ & $43.3^{*}$ \\
\hline & 30 & 15.8 & 9.3 \\
\hline \multirow[t]{4}{*}{ Abdominal plates } & 4 & 0.0 & 6.2 \\
\hline & 5 & 43.2 & 73.2 \\
\hline & 6 & 55.8 & 20.6 \\
\hline & 7 & 1.1 & 0.0 \\
\hline \multirow[t]{2}{*}{ Dorsal plates } & 3 & 94.7 & 99.0 \\
\hline & 4 & 5.3 & 1.0 \\
\hline \multirow[t]{3}{*}{ Plates on dorsal interradial membrane } & 11 & 5.3 & 7.2 \\
\hline & 12 & 91.6 & 85.6 \\
\hline & 13 & 3.2 & 7.2 \\
\hline \multirow[t]{2}{*}{ Plates on anal interradial membrane } & 2 & 93.7 & 70.1 \\
\hline & 3 & 6.3 & 29.9 \\
\hline
\end{tabular}


TABLE 1 (continue)

\begin{tabular}{|c|c|c|c|}
\hline Characters & Count & $\begin{array}{l}\% \text { P. disjunctivus } \\
(\mathrm{N}=96)\end{array}$ & $\begin{array}{l}\% \text { P. pardalis } \\
(\mathrm{N}=97)\end{array}$ \\
\hline \multirow[t]{2}{*}{ Plates on pectoral interradial membrane } & 1 & 98.9 & 100.0 \\
\hline & 2 & 1.1 & 0.0 \\
\hline \multirow[t]{2}{*}{ Plates on pelvic interradial membrane } & 2 & 98.9 & 100.0 \\
\hline & 3 & 1.1 & 0.0 \\
\hline \multirow[t]{5}{*}{ Plates on adpressed pectoral fin } & 5 & 1.1 & 21.6 \\
\hline & 6 & 8.4 & 26.8 \\
\hline & 7 & 51.6 & 35.1 \\
\hline & 8 & 24.2 & 13.4 \\
\hline & 9 & 14.7 & 3.1 \\
\hline \multirow[t]{7}{*}{ Plates on adpressed pelvic fin } & 6 & 1.1 & 7.2 \\
\hline & 7 & 23.2 & 12.4 \\
\hline & 8 & 34.7 & 32.0 \\
\hline & 9 & 27.4 & 29.9 \\
\hline & 10 & 12.6 & 14.4 \\
\hline & 11 & 1.1 & 3.1 \\
\hline & 12 & 0.0 & 1.0 \\
\hline \multirow[t]{7}{*}{ Postanal plates } & 11 & 5.3 & 0.0 \\
\hline & 12 & 6.3 & 2.1 \\
\hline & 13 & $29.5 *$ & 21.6 \\
\hline & 14 & 30.5 & $51.5^{*}$ \\
\hline & 15 & 17.9 & 20.6 \\
\hline & 16 & 9.5 & 4.1 \\
\hline & 17 & 1.1 & 0.0 \\
\hline \multirow[t]{4}{*}{ Plates between dorsal fin base and adipose fin } & 5 & 0.0 & 2.1 \\
\hline & 6 & 34.7 & $48.5^{*}$ \\
\hline & 7 & $62.1 *$ & 48.5 \\
\hline & 8 & 3.2 & 1.0 \\
\hline
\end{tabular}

*Mode for each species as reported by Weber (1992).

Both species of Pterygoplichthys were collected from the five study sites except in Pasig River in the City of Manila where only P. disjunctivus was noted. Current distributions of the two Pterygoplichthys species are shown in Fig. 5. The fishes caught from Pasig River, Marikina River, Banilad Creek, and Catmon Creek were collected from medium-velocity rivers no more than two meters deep near the riverbanks. Specimens were caught with cast nets except those from Pasig River, which were hand-caught. Most of the drainages where specimens were collected have a muddy and murky bottom. Water quality in these areas can be characterized generally as polluted because these drainages receive waste materials and even sewage from households and industries. Breeding 

Marikina River were noted to move upstream during high tide to avoid the intrusion of saline water from Manila de Bay. Specimens from San Pedro, Laguna, were collected from fish traps about 2-4 meters deep in the lake waters. This collection site is also situated near heavily populated communities. All fishes were caught during daytime.

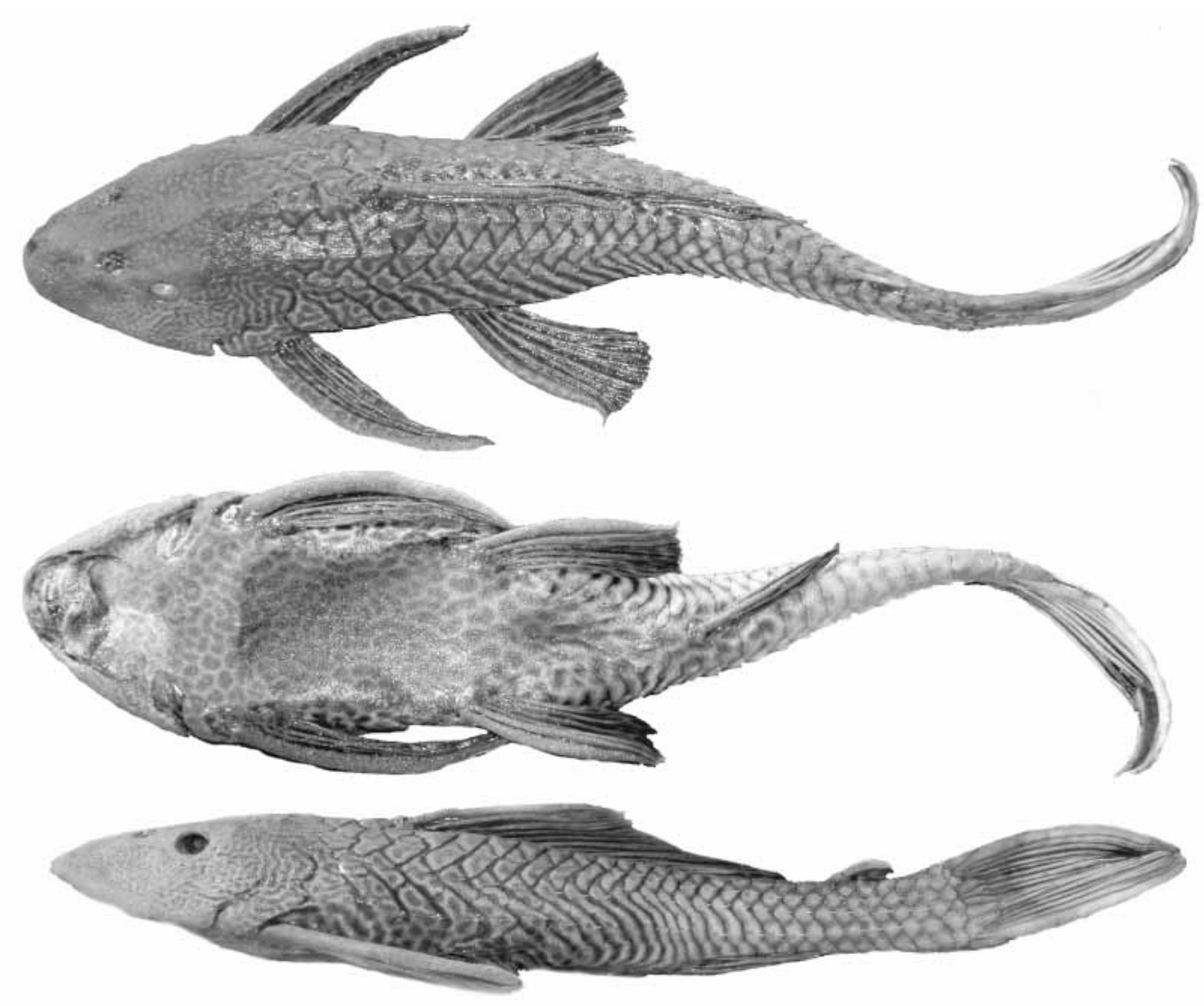

FIGURE 2. Pterygoplichthys pardalis from Laguna de Bay (DLSU ZC-F 61002. SL 223.0 mm. Collected by J. R. Carandang. Photo by J.M. Chavez).

Our results do not dispel the presence of Hypostomus plecostomus as local reports claimed. However, our results establish the fact that the janitor fish commonly encountered in the Laguna de Bay basin are species of the genus Pterygoplichthys.

Species of Pterygoplichthys, commonly known as sailfin catfishes, are native to South America. When and how sailfin catfishes were introduced into Philippine waters are unknown. We suspect that the first individuals were imported from the United States as aquarium fishes, where species of Pterygoplichthys have been introduced in Texas, Florida, Nevada, and Hawaii (Hoover et al., 2004, Sabaj \& Englund 1999). 


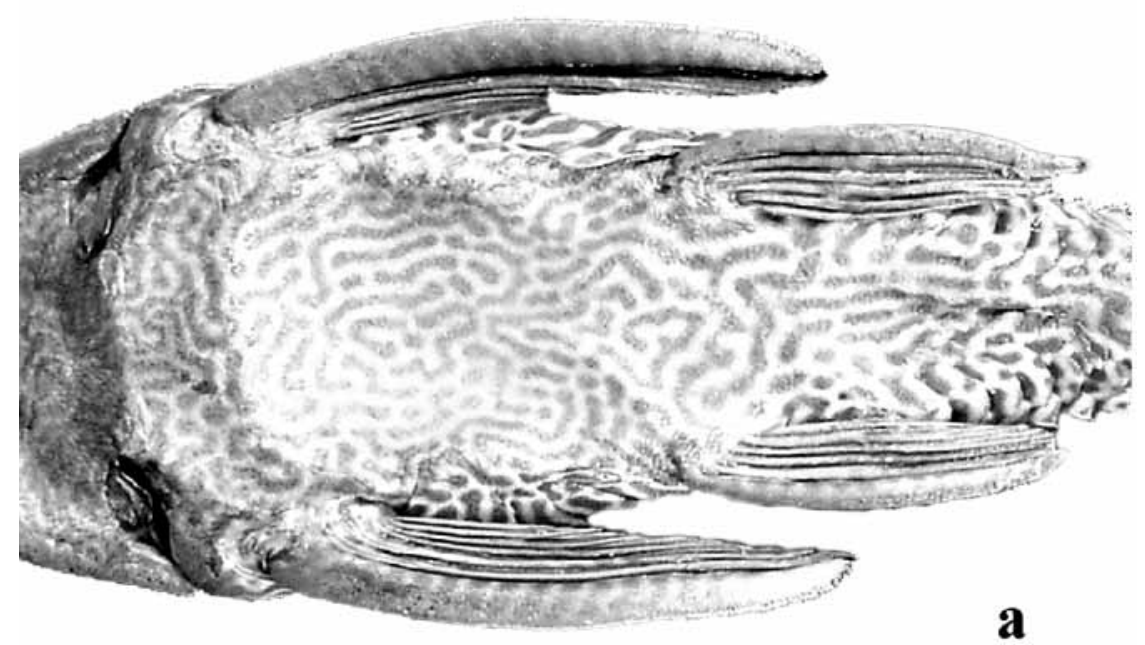

ZOOTAXA

1109
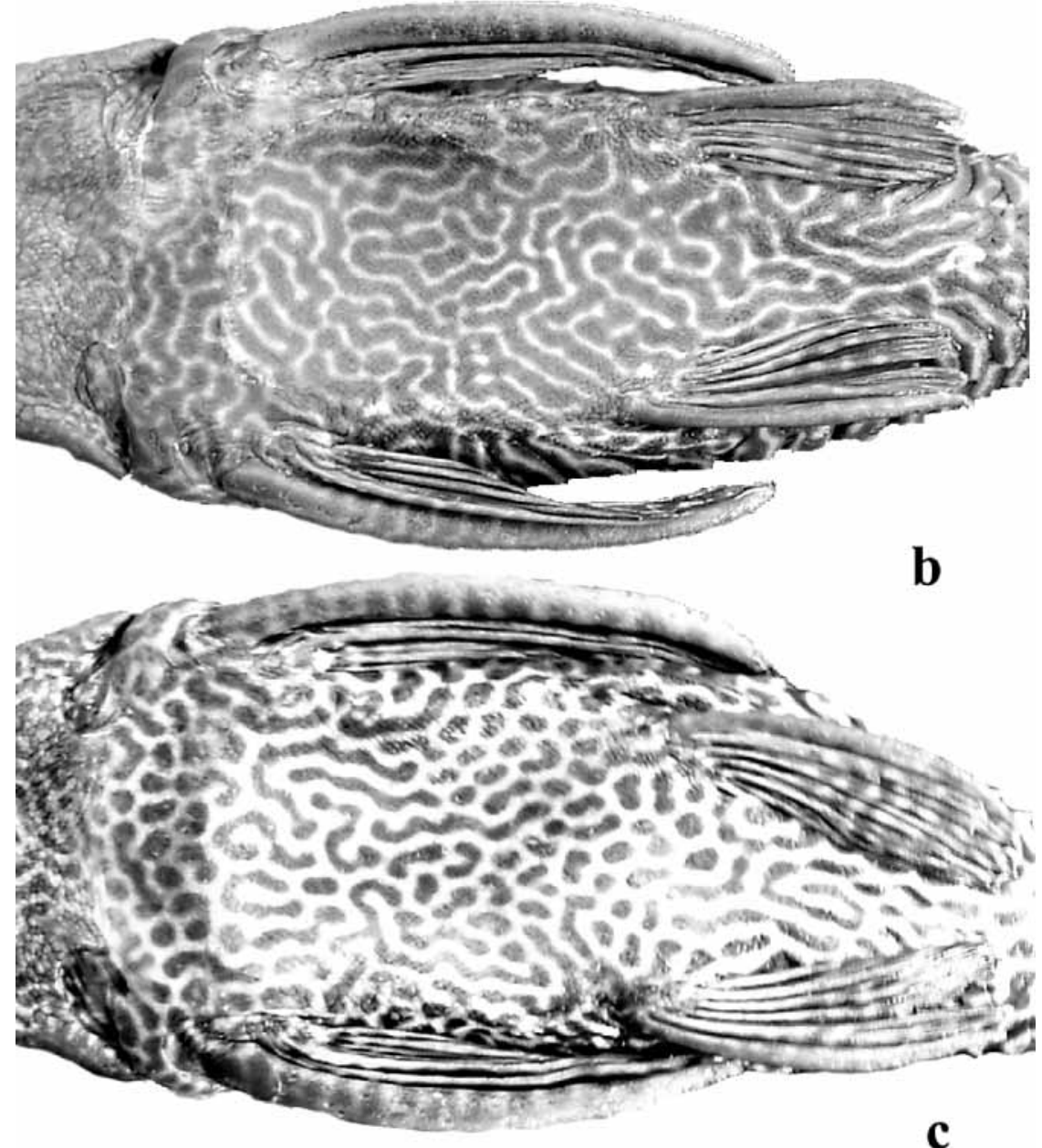

FIGURE 3. Variations in abdominal color patterns in Pterygoplichthys disjunctivus collected from Laguna de Bay. (A) DLSU ZC-F 31020, SL 318.9 mm. (B) DLSU ZC-F, 31039 SL $259.1 \mathrm{~mm}$. (C) DLSU ZC-F 31028, SL 324.5 mm. Photo by J.M. Chavez. 


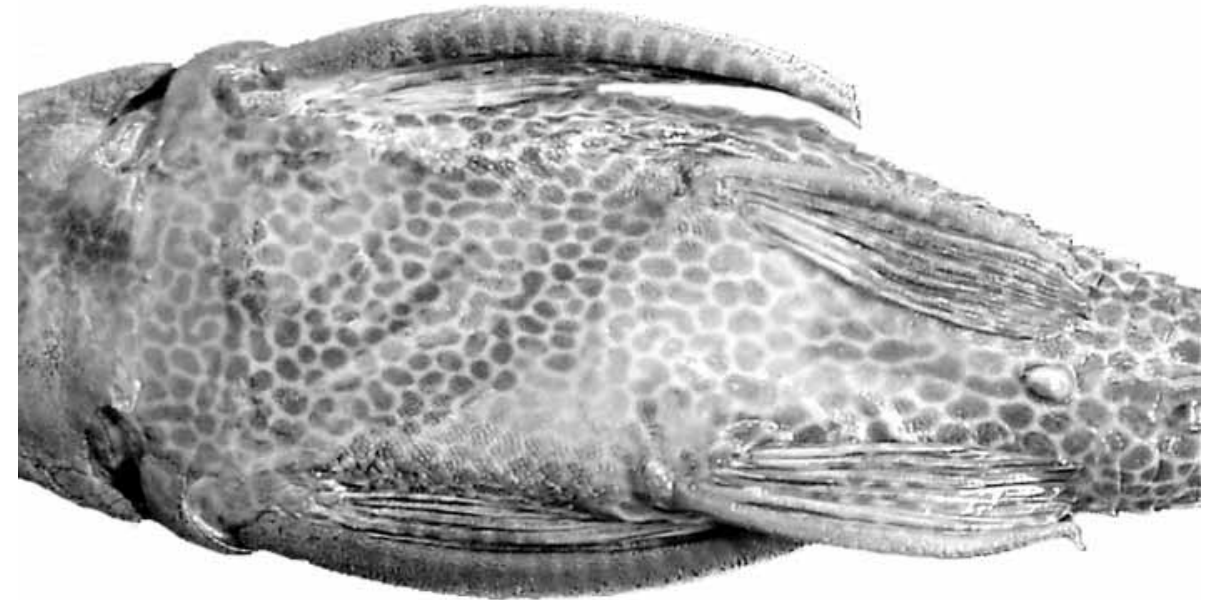

FIGURE 4. Abdomen of Pterygoplichthys pardalis collected from Laguna de Bay (DLSU ZC-F 31009 SL 317.6 mm. Photo by J.M. Chavez.

TABLE 2. Selected morphometric features of Pterygoplichthys species from the Laguna de Bay area.* The following abbreviations are used: $\mathrm{SL}=$ standard length; L. = length; Dis. = distance; Dep. $=$ depth; and $\mathrm{W} .=$ width .

\begin{tabular}{|c|c|c|c|c|c|c|c|c|}
\hline \multirow[t]{2}{*}{ Measurement } & \multicolumn{4}{|c|}{ P. disjunctivus } & \multicolumn{4}{|c|}{ P. pardalis } \\
\hline & $\overline{\mathrm{N}}$ & Range & Mean & SD & $\overline{\mathrm{N}}$ & Range & Mean & SD \\
\hline$\overline{\mathrm{SL}}$ & 96 & $93.1-399.3$ & 304.5 & 68.8 & 97 & $76.1-422.9$ & 225.3 & 95.4 \\
\hline Predorsal L. & 96 & $34.3-46.6$ & 41.5 & 2.4 & 97 & $20.3-47.3$ & 41.4 & 3.8 \\
\hline Head L. & 96 & $23.2-34.4$ & 30.2 & 2.1 & 97 & $26.7-35.1$ & 30.9 & 1.8 \\
\hline Head dorsal L. & 96 & $6.9-15.1$ & 11.9 & 1.6 & 97 & $6.7-40.5$ & 11.8 & 3.4 \\
\hline Cleithral W. & 96 & $19.4-29.3$ & 23.4 & 2.1 & 97 & $20.2-32.7$ & 25.3 & 2.6 \\
\hline Head pectoral L. & 96 & $18.8-32.6$ & 26.1 & 3.0 & 97 & $18.9-32.5$ & 25.5 & 2.7 \\
\hline Thorax L. & 96 & $16.3-28.2$ & 22.4 & 2.2 & 97 & $16.8-27.9$ & 22.6 & 2.4 \\
\hline Pectoral spine L. & 96 & $17.4-36.0$ & 29.4 & 2.9 & 97 & $3.2-35.4$ & 28.8 & 4.1 \\
\hline Abdominal L. & 96 & $2.4-25.6$ & 21.9 & 2.9 & 97 & 15.9-28.9 & 22.1 & 2.2 \\
\hline Pelvic spine L. & 96 & $14.4-25.4$ & 19.6 & 2.3 & 97 & $11.8-26.3$ & 21.2 & 2.8 \\
\hline Postanal L. & 96 & $19.8-43.2$ & 32.9 & 2.9 & 97 & $21.1-37.7$ & 32.5 & 2.7 \\
\hline Anal fin spine L. & 96 & $6.8-19.2$ & 13.3 & 2.6 & 97 & $7.8-19.6$ & 14.4 & 2.5 \\
\hline Dorsal pectoral Dis. & 96 & $18.8-31.2$ & 23.0 & 2.1 & 97 & $2.5-29.0$ & 23.0 & 3.1 \\
\hline Dorsal spine L. & 96 & $13.1-28.4$ & 20.5 & 2.9 & 97 & $13.4-30.8$ & 21.9 & 3.4 \\
\hline Dorsal pelvic Dis. & 96 & $14.1-24.5$ & 19.6 & 2.3 & 97 & $14.0-27.2$ & 20.6 & 2.5 \\
\hline Dorsal fin base L. & 96 & $28.1-38.0$ & 32.4 & 1.9 & 97 & $3.2-39.3$ & 32.7 & 3.6 \\
\hline
\end{tabular}


TABLE 2 (continue)

\begin{tabular}{|c|c|c|c|c|c|c|c|c|}
\hline \multirow[t]{2}{*}{ Measurement } & \multicolumn{4}{|c|}{ P. disjunctivus } & \multicolumn{4}{|c|}{ P. pardalis } \\
\hline & $\mathrm{N}$ & Range & Mean & SD & $\mathrm{N}$ & Range & Mean & SD \\
\hline Dorsal adipose Dis. & 96 & $11.6-20.0$ & 16.0 & 1.8 & 97 & $10.9-19.8$ & 15.3 & 1.5 \\
\hline Adipose spine L. & 96 & $3.4-9.4$ & 6.1 & 1.1 & 97 & $4.1-9.9$ & 6.8 & 1.2 \\
\hline Dorsal adipose caudal Dis. & 96 & $8.0-17.1$ & 11.2 & 1.8 & 97 & $7.8-14.7$ & 11.8 & 1.6 \\
\hline Caudal peduncle Dep. & 96 & $8.7-13.4$ & 10.7 & 1.0 & 97 & $8.3-13.2$ & 11.0 & 1.0 \\
\hline Ventral adipose caudal Dis. & 96 & $13.3-21.1$ & 16.5 & 1.6 & 97 & $13.1-21.4$ & 17.0 & 1.5 \\
\hline Adipose anal Dis. & 96 & $15.7-26.9$ & 21.5 & 1.7 & 97 & $16.3-25.2$ & 21.1 & 1.7 \\
\hline Dorsal anal Dis. & 96 & $9.1-15.1$ & 11.9 & 1.2 & 97 & $9.7-15.1$ & 12.6 & 1.2 \\
\hline Pelvic dorsal Dis. & 96 & $23.0-33.4$ & 27.3 & 2.3 & 97 & $21.7-33.0$ & 27.6 & 2.7 \\
\hline Total L. & 96 & $125.2-503.9$ & 380.7 & 6.5 & 96 & $102.1-514.9$ & 289.8 & 7.4 \\
\hline Preanal Dis. & 96 & $59.0-80.0$ & 69.1 & 3.2 & 97 & $56.8-75.8$ & 69.2 & 3.3 \\
\hline Head eye L. & 96 & $30.3-53.6$ & 41.8 & 4.5 & 97 & $25.9-71.3$ & 40.4 & 7.8 \\
\hline Orbit diameter & 96 & $6.5-21.4$ & 10.6 & 2.5 & 97 & $7.3-23.1$ & 13.8 & 4.3 \\
\hline Snout L. & 96 & $35.5-60.8$ & 49.8 & 4.9 & 97 & $26.4-57.2$ & 47.3 & 5.1 \\
\hline Internares W. & 96 & $2.4-38.1$ & 27.5 & 3.7 & 97 & $1.8-39.3$ & 27.6 & 3.9 \\
\hline Interorbital W. & 96 & $40.8-67.6$ & 49.4 & 4.5 & 97 & $38.9-68.3$ & 52.2 & 6.0 \\
\hline Head depth & 96 & $42.8-69.2$ & 55.8 & 6.5 & 97 & $37.7-86.7$ & 56.4 & 7.6 \\
\hline Mouth L. & 96 & $21.8-48.2$ & 34.3 & 5.3 & 97 & $18.9-45.7$ & 34.9 & 5.3 \\
\hline Mouth W. & 96 & $22.1-45.6$ & 34.0 & 4.2 & 97 & $24.0-44.0$ & 34.7 & 4.6 \\
\hline Barbel L. & 96 & $5.7-22.7$ & 13.3 & 3.6 & 97 & $6.9-22.3$ & 12.6 & 2.7 \\
\hline Dentary tooth cup L. & 96 & $8.7-15.8$ & 12.1 & 1.4 & 97 & $6.9-18.1$ & 11.8 & 1.9 \\
\hline Premaxillary tooth cup L. & 96 & $7.7-18.0$ & 11.4 & 1.6 & 97 & $5.0-20.1$ & 10.6 & 2.2 \\
\hline
\end{tabular}

* SL in mm. Predorsal to preanal measurements are ratios of SL. Head eye length to premaxillary tooth cup length are ratios of head length.

Sailfin catfishes are popular in the Philippines as aquarium pets. Local aquarium dealers have used its local moniker as a selling point and over the years the misconception-that a "janitor fish" cleans uphas risen. Anecdotal reports say this misconception might also be a reason for the high incidence of sailfin catfishes particularly in the Marikina and Pasig Rivers. These drainages have been subjects of clean up drives by local government agencies and private organizations in the past.

Species of Pterygoplichthys are not the first non-native species of fishes introduced in Philippine waters through the ornamental fish trade (Juliano et al., 1989). We suspect a wider distribution of Pterygoplichthys species outside of the Laguna de Bay basin due to its popularity and the extent and briskness of the aquarium fish trade in the Philippines. We have received reports of "janitor fish" sightings in streams and rivers in Zamboanga City (about $850 \mathrm{Km}$ south of the City of Manila) and Aparri Cagayan (about $420 \mathrm{Km}$ north of the City of Manila). 
TABLE 3. Comparison between measurements of locally caught Pterygoplichthys species against measurements by Weber (1992). (Measurement abbreviations are: L=length, D=distance, Dia=diameter, $\mathrm{Dp}=$ depth. Sites are coded as follows: $1=$ Catmon Creek; $2=$ Marikina River; $3=$ Laguna de Bay; 4 = Pasig River; 5 = Banilad Creek.)

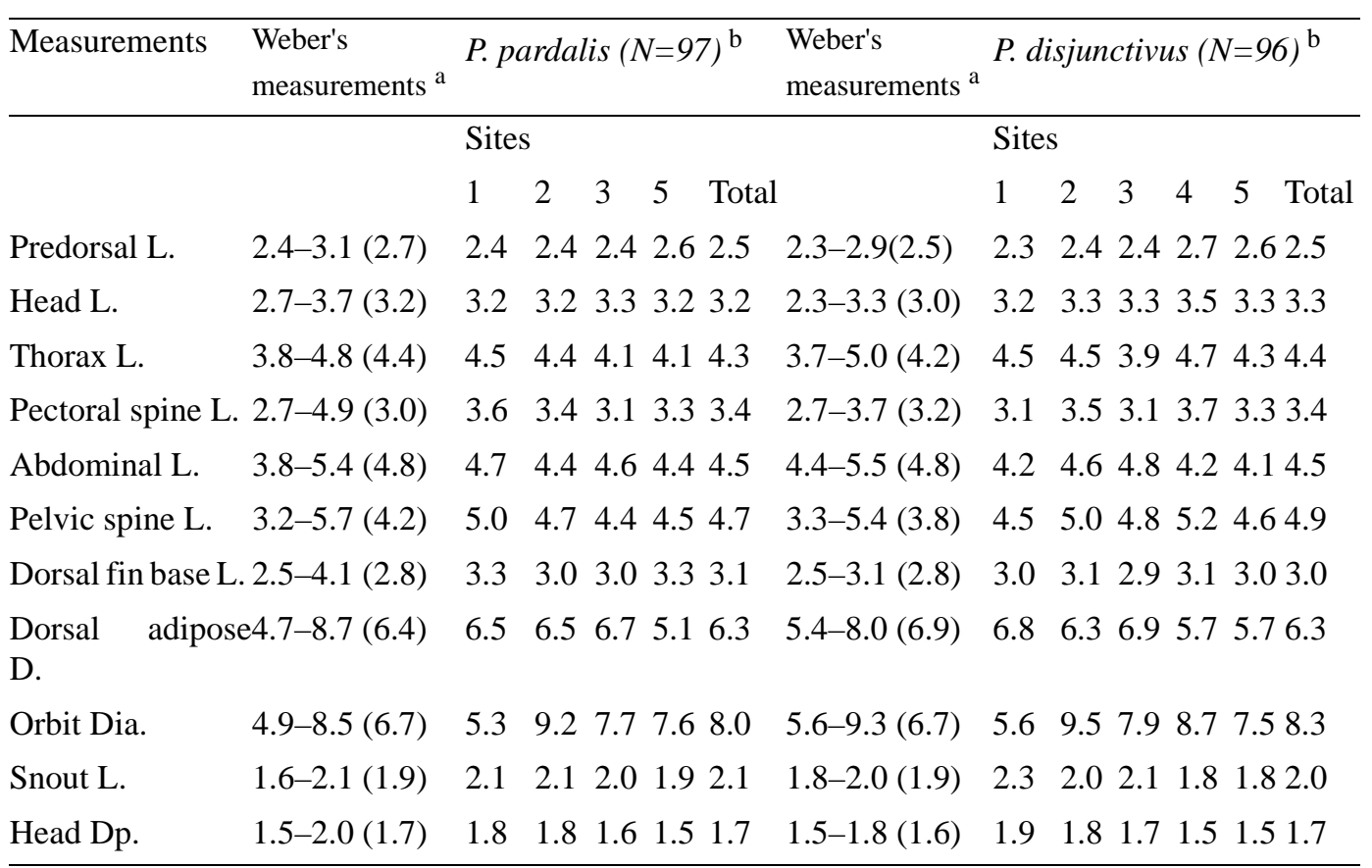

${ }^{\text {a }}$ Range of measurements. The averages are enclosed in parenthesis.

${ }^{b}$ Quantities are the mean measurements per site. Column "total" represents the mean of all sites per measurement.

\section{Acknowledgements}

We thank Drs. Jonathan Armbruster of Auburn University and Claude Weber of the Natural History Museum of Geneva for verifying identifications of the specimens. Mr. Elpidio Retes and Ms. Jesusahan Marzan of the Biology Department, De La Salle University, provided technical assistance for this study. We also thank Mr. Roger Arambulo of the Barangay Council of Ugong, Pasig, the officials and staff of the Barangay Hall of Sto. Nino, Marikina City, and the $105^{\text {th }}$ Auxillary Squadron of the Philippine Coast Guard for facilitating the collections in Marikina River and Pasig River. Dr. Emmanuel Ramos of the Manila Observatory at the Ateneo de Manila University provided the drainage map of Laguna de Bay basin with the plot of coordinates. This study was funded in part by the Philippine Commission on Higher Educations Center of Excellence Project at the Biology Department of De La Salle University. 


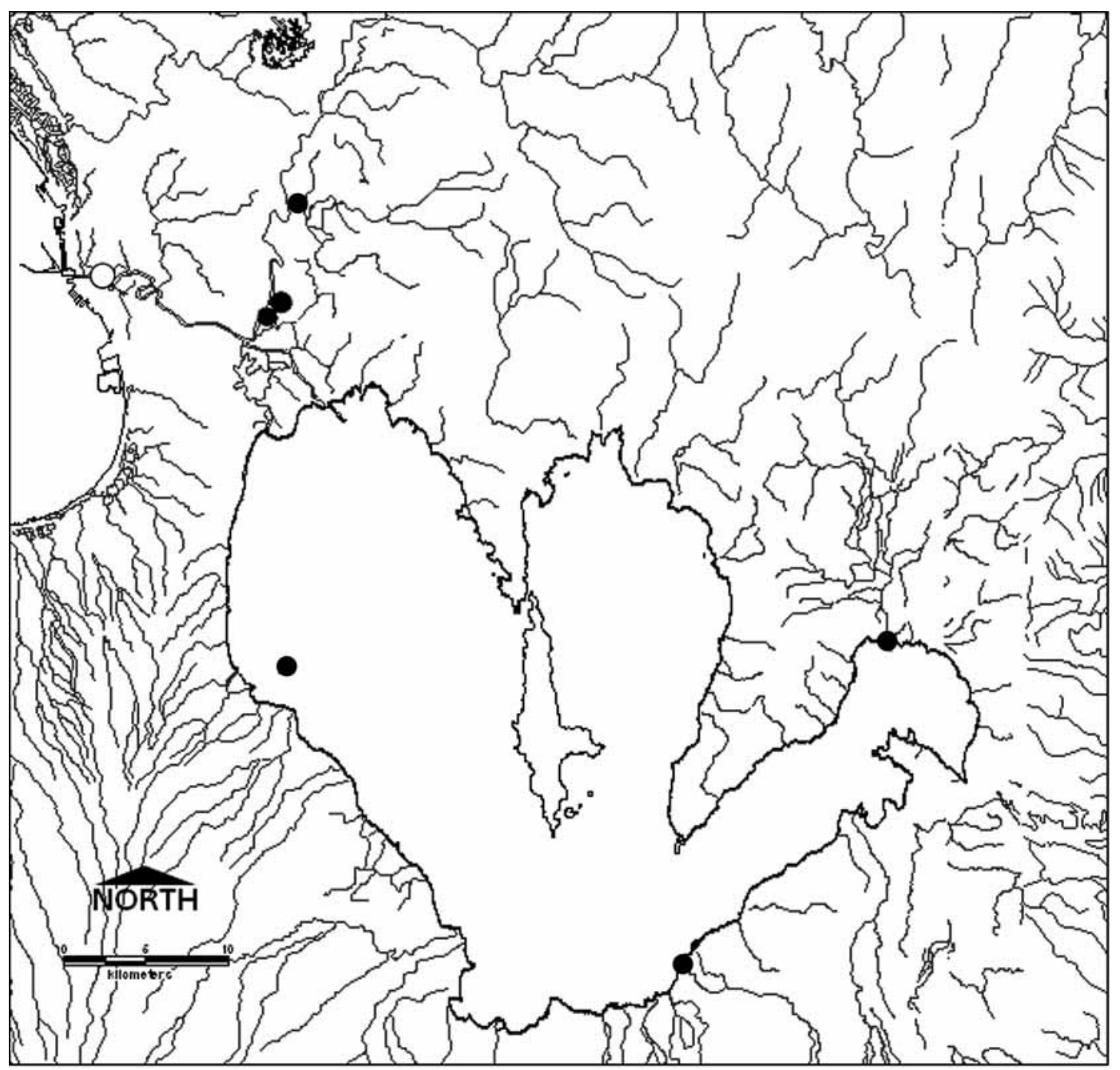

FIGURE 5. Current range of $P$. pardalis and $P$. disjunctivus in the Laguna de Bay basin. Open symbol represents $P$. disjunctivus only.

\section{References}

Armbruster, J. (1997) Phylogenetic Relationships of the Sucker-Mouth Armored Catfishes (Loricariidae) with Particular Emphasis on Ancistrinae, Hypostominae and Neoplecostominae Ph.D. Dissertation, University of Illinois, Urbana-Champaign, $433 \mathrm{pp}$

Armbruster, J. (1998) Review of the loricariid catfish genus Aphanotorulus and redescription of $A$. unicolor (Teleostei: Siluriformes). Ichthyological Exploration of Freshwaters, 8 (3), 253- 262

Armbruster, J. (2002a) Hypancistrus inspector: A new species of suckermouth armored catfish (Loricariidae: Ancistrinae). Copeia, 2002, 86-92

Armbruster, J. (2002b) A key to the genera of Loricariidae. Available from http://george.cosam. auburn.edu/usr/key_to_loricariidae/key.html (accessed 4 July 2004)

Armbruster, J. (2003a) Peckoltia sabaji, a new species from the Guyana Shield (Siluriformes: Loricariidae). Zootaxa, 344, 1-12 
Armbruster, J. (2003b) The species of the Hypostomus cochliodon group (Siluriformes: Loricariidae). Zootaxa 249: 1-60

Armbruster, J. (2004) Phylogenetic relationships of the suckermouth armoured catfishes (Loricariidae) with emphasis on the Hypostominae and the Ancistrinae. Zoological Journal of the Linnaean Society, 141, 1-80.

Armbruster, J. \& Hardman, M. (1999) Redescription of Pseudorinelepis genibarbis (Loricariidae: Hypostominae) with comments on behavior as it relates to air holding. Ichthyological Exploration of Freshwaters, 10 (1), 53-61

Armbruster, J. \& Page, L. (1996) Redescription of Aphanotorulus (Teleostei: Loricariidae) with description of one new species, A. ammophilus from the Rio Orinoco Basin. Copeia, 1996, 379-389

Armbruster, J. \& Provenzano, F. (2000) Four new species of the suckermouth armored catfish genus Lasiancistrus (Loricariidae: Ancistrinae). Ichthyological Exploration of Freshwaters, 11(3), 241-254

Armbruster, J., Sabaj, M., Hardman, M., Page, L., \& Knouft, J. (2000) Catfish genus Corymbophanes (Loricariidae: Hypostominae) with description of one new species: Corymbophanes kaiei. Copeia, 2000, 997-1006

Hoover, J., Killgore, J. \& Cofrancesco, A. (2004) Suckermouth catfishes: Threats to aquatic ecosystems of the United States? Aquatic Nuisance Species Research Program Bulletin 4-1. U.S. Army Corp of Engineers Research and Development Center, Vicksburg, Mississippi. Available from http://el.erdc.usace.army.mil:80/elpubs/pdf/ansrp-v04-1.pdf (accessed 14 December 2004)

Juliano, R. Guerrero III, R. \& Ronquillo, I. (1989) The introduction of exotic species in the Philippines. In: S.S. De Silva (ed.) Exotic Aquatic Organisms in Asia. Proceedings of the Workshop on Introduction of Exotic Aquatic Organisms in Asia. Asian Fisheries Society Special Publication 3. Asian Fisheries Society, Manila, Philippines, pp. 83-90

Sabaj, M. \& Englund, R. (1999) Preliminary identification and current distributions of two suckermouth armored catfishes (Loricariidae) introduced in Oahu Streams. Bishop Museum Occasional Papers. 59, 50-55

Weber, C. (1992) Revision de genre Pterygoplichthys sensu lato (Pisces, Siluriformes, Loricariidae). Revue Francaise d'Aquariologie Herpetologie, 19, 1-36 